\title{
Perbedaan Hasil Belajar Sejarah dengan Menggunakan Model Pembelajaran Student Facilitator and Explaining dan Mind Mapping Kelas X Di SMA Plus Bina Satria Rupit
}

\author{
Getsah Afriweni ${ }^{1}$, Ira Miyarni ${ }^{2}$, Sarkowi $^{3}$ \\ ${ }^{1}$ STKIP PGRI Lubuklinggau, Lubuklinggau, Indonesia \\ ${ }^{2}$ STKIP PGRI Lubuklinggau, Lubuklinggau, Indonesia \\ ${ }^{3}$ STKIP PGRI Lubuklinggau, Lubuklinggau, Indonesia
}

1'getsaafriweni028@gmail.com, ${ }^{2}$ irastkip@gmail.com, ${ }^{3}$ sarkowisulaiman@gmail.com

\begin{tabular}{ccc}
\hline Received & Accepted & Published \\
$05 / 10 / 2020$ & $10 / 08 / 2021$ & $21 / 08 / 2021$ \\
\hline
\end{tabular}

\begin{abstract}
This study aims to determine the differences in the results of learning history using the Student Facilitator And Explaining and Mind Mapping Class X learning model at SMA Plus Bina Satria Rupit. The research method used in this study was a quasi-experimental with random sampling method. The average result of the pre-test in the experimental class I was 55.18 and in the experimental class II was 54.3. while the post-test average value in the experimental class I after being given post-test treatment using the Student Facilitator And Expalinning model was 81.32, and in the experimental class II given Mind Mapping learning was 76.53. Based on the results of data analysis using the average difference test (Paired sample $T$ test) obtained the final test value in sig. (2-Tiled) $=0.00<0.05$, then Ho is rejected, Ha is accepted. Thus, it can be concluded that there are differences in the results of learning history using the Student Facilitator And Explaining and Mind Mapping Class X learning model at SMA Plus Bina Satria Rupit.
\end{abstract}

Keywords: Student Facilitator And Explaining, Mind Mapping, Learning Outcomes

\begin{abstract}
Abstrak Penelitian ini bertujuan untuk mengetahui perbedaan hasil belajar sejarah dengan menggunakan model pembelajaran Student Facilitator And Explainning dan Mind Mapping Kelas $X$ di SMA Plus Bina Satria Rupit. Metode penelitian yang digunakan dalam penelitian ini adalah eksperimen semu dengan metode random sampling. Hasil rata-rata pre-test pada kelas eksperimen I sebesar 55,18 dan pada kelas eksperimen II sebesar 54,3. sedangkan nilai rata-rata post-test pada kelas eksperimen I setelah diberi perlakuan post-test dengan menggunakan model Student Facilitator And Expalinning sebesar 81,32, dan pada kelas eksperimen II yang diberikan pembelajaran Mind Mapping sebesar 76,53. Berdasarkan hasil analisis data menggunakan uji beda rata-rata (Paired sampel $T$ test) diperoleh nilai tes akhir di sig. (2-Tiled) $=0,00<0,05$, maka Ho di tolak Ha diterima. Dengan demikian, ditarik kesimpulan bahwa ada perbedaan hasil belajar sejarah dengan menggunakan model pembelajaran Student Facilitator And Explainning dan Mind Mapping Kelas X di SMA Plus Bina Satria Rupit.
\end{abstract}

Kata kunci : Student Facilitator And Explaining, Mind Mapping, Hasil Belajar 


\section{PENDAHULUAN}

Pendidikan merupakan suatu proses pembelajaran yang dilakukan agar peserta didik secara aktif mengembangkan potensi dirinya untuk memiliki kekuatan seperti keagamaan, kepribadian, pengendalian diri, kecerdasan, akhlak mulia, serta keterampilan yang diperlukan dirinya masyarakat bangsa dan negara. Pada proses pendidikan dan pembelajaran guru sangat berperan penting. Menurut Triwiyanto (2014:66) "Pendidikan adalah upaya yang sengaja untuk membantu pertumbuhan dan perkembangan murid. Pada proses pendidikan dan pembelajaran guru sangat berperan penting. Menurut Aunurrahhman (2016:4), "Guru memegang peran strategis terutama dalam upaya membentuk watak bangsa melalui pengembangan kepribadian dan nilai-nilai yang diinginkan. Dari uraian tersebut dapat dipahami bahwa guru memegang peran penting dalam pembelajaran di kelas yang dapat menghasilkan suatu perubahan baik watak maupun kepribadian terhadap siswa. Pada proses pembelajaran berlangsung guru sebagai pendidik mempunyai tugas".

Hasil belajar siswa diharapkan dapat mencapai KKM (Kriteria Ketuntasan Minumum) yang telah ditetapkan, serta prestasi belajar siswa dapat meningkat setelah adanya proses belajar dalam proses pembelajaran, hasil belajar merupakan tolak ukur menilai hasil belajar siswa. Dari pendapat tersebut maka dapat dipahami bahwa hasil belajar adalah perubahan perilaku yang terjadi setelah seseorang melakukan proses pembelajaran, perubahan perilaku tersebut mencakupi secara keseluruhan yaitu, afektif, kognitif, dan psikomotorik.

Berdasarkan hasil observasi yang dilaksanakan pada tanggal 10-16 Januari 2020 di SMA Plus Bina Satria Rupit yang diperoleh keterangan Ibu Sri Anggraini S.Pd, dan Ibu Elia Nursahada, S.Pd, selaku guru bidang studi Sejarah SMA Plus Bina Satria Rupit dan pelaksanaan PPP (Penerapan Perangkat Pembelajaran) yang pernah peneliti laksanakan di SMA Plus Bina Satria Rupit, bahwa pada kenyataannya masih banyak siswa kelas X yang kurang memiliki minat dan partisipasi ketika belajar mata pelajaran sejarah, selain itu siswa juga sulit dalam menganalisa, memahami suatu materi serta memecahkan masalah dalam menyelesaikan pembelajaran sejarah. Hal tersebut menunjukkan siswa menjadi kurang aktif dan kreatif dalam berpikir atau cenderung pasif ketika berlangsungnya kegiatan belajar mengajar.Hanya siswa-siswa tertentu saja yang serius dan mengikuti pelajaran sejarah dengan baik.Kemudian penulis juga mendapat keterangan dari beberapa siswa bahwa kegiatan belajar mengajar sejarah yang mereka tempuh itu kurang menarik.Hal ini disebabkan karena kondisi mata pelajaran sejarah kurang bervariasi dan membuat siswa cepat merasa jenuh dan bosan.

SMA Plus Bina Satria Rupit melakukan proses pembelajaran menggunakan kurikulum 2013 (K13). Sebagai pedoman atau acuan sistem didalam pembelajaran yang dilaksanakan pada Sekolah, maka sekolah menggunakan K13 siswa dianjurkan lebih aktif dibanding gurunya. Namun dalam kegiataan observasi bapak Asep Komarudin S.Pd,I sebagai wakil ketua kurikulum 
dan ibu Sri Agustina S,Pd, Keadaan demikian mengakibatkan sebagian besar siswa belum mencapai nilai KKM (Kriteria Ketuntasan Minimum)pada mata pelajaran sejarah yang telah ditetapkan oleh pihak sekolah sebesar 70. Secara umum pada kompetensi dasar dalam memahami prinsip dasar ilmu sejarah dari 124 siswa kelas X SMA Plus Bina Satria yang terbagi dalam Empat kelas hanya 48 siswa (38,70 \%) yang mencapai KKM (70), sedangkan 76 (61,30 \%) orang siswa lainnya belum mencapai KKM.

Model pembelajaran adalah suatu pola pembelajaran yang mengacu pada pendekatan termasuk di dalamnya tahap-tahap, tujuan-tujuan pembelajaran, kegiatan pembelajaran, memberi petunjuk, mengatur materi pembelajaran dan mengelola kelas. Salah satunya model pembelajaran diantaranya model pembelajaran yang dapat meningkatkan hasil belajar adalah model pembelajaran Student Facilitator And Explainning dan Model Pembelajaran Mind Mapping. Menurut Huda (2014:228-229), “Model pembelajaran Student Facilitator and Explainning merupakan rangkai penyajian materi ajar yang diawali dengan penjelasan secara terbuka, memberi kesempatan siswa untuk menjelaskan kembali kepada rekan-rekannya, dan diakhiri dengan penyampaian semua materi kepada siswa. Kuncinya adalah bahwa semua materi yang bisa didemonstrasikan pada hakikatnya juga bisa disajikan melalui strategi Student Facilitator And Explainning".

Menurut Kurniasih, Sani (2016:53), “Mind Mapping merupakan cara untuk menempatkan informasi kedalam otak dan mengambilnya kembali ke luar otak. Mind Mapping disebut pemetaan pikiran atau peta pikiran merupakan salah satu cara mencatat materi pelajaran yang memudahkan siswa belajar. Dalam penjelasan yang lebih sederhana, peta pikiran (mind mapping) adalah satu teknik yang mengembangkan gaya belajar visual. Peta pikiran memadukan dan mengembangkan potensi kerja otak terdapat di dalam diri seseorang".

Berdasarkan penjelasan di atas, model pembelajaran Student Facilitator And Explainning dan Model pembelajaran Mind Mapping dapat menyelesaikan masalah belajar siswa dan mampu meningkatkan hasil belajar siswa pada pelajaran sejarah. Oleh karena itu peneliti, melakukan penelitian dengan judul "Perbedaan Hasil Pembelajaran Sejarah Model Pembelajaran Student Facilitator And Explainning dan Model Pembelajaran Mind Mapping Kelas X di SMA Plus Bina Satria".

\section{METODE}

Menurut Sugiyono (2017:14) mengatakan bahwa, "Penelitian Kuantitatif dapat diartikan sebagai metode penelitian yang berlandaskan pada filsafat positivisme, digunakan untuk meneliti pada populasi atau sampel tertentu, teknik pengambillan sampel pada umumnya dilakukan secara random, pengumpulan data menggunakan instrumen penelitian, analisis data bersifat kuantitatif/statistik dengan tujuan untuk menguji hipotesis yang telah ditetapkan". 
Jenis penelitian yang digunakan dalam penelitian ini adalah jenis quasi experimen design (eksperimen semu) dengan desain pretest-posttest nonequivalent. Pemilihan metode quasi experimen design (eksperimen semu) dikarenakan pada penelitian ini untuk mengetahui seberapa besar perbedaan yang diterapkan dua perlakuan (treatment) yaitu model pembelajaran Student Facilitator And Explainning dan model pembelajaran Mind Mapping terhadap hasil belajar siswa. Adapun tujuan penelitian ini adalah untuk mengumpulkan dan memperoleh data serta informasi yang diperlukan sehingga dapat mengetahui perbedaan hasil pembelajaran Sejarah model pembelajaran Student Facilitator And Explainning dan model pembelajaran Mind Mapping kelas X di SMA Plus Bina Satria Rupit.

Desain penelitian ini berbentuk Pre Test-Postest Control Grup Design, yang merupakan penelitian dengan 2 kelas, dibuktikan dengan adanya kelas eksperimen I dan kelas eksperimen II. Selanjutnya menurut Sugiyono (2017:117), "Populasi adalah wilayah generalisasi yang terdiri atas, obyek/subyek yang mempunyai kualitas dan karakteristik tertentu yang ditetapkan oleh peneliti, kesimpulannya." Jadi populasi dapat didefinisikan sebagai seluruh jumlah subjek dari penelitian.

Menurut Thobroni (2015:20) menjelaskan "Hasil belajar adalah pola-pola perbuatan, nilai-nilai, pengertian-pengertian, sikap-sikap, apresiasi, dan keterampilan". Teknik Pengumpulan data yang digunakan pada penelitian ini adalah tes. Menurut Sudjiono (2010:66), "Tes adalah alat atau prosedur yang dipergunakan dalam rangka pengukuran dan penilaian." Menurut Arikunto (2010:211) "Validitas adalah suatu ukuran yang menunjukkan tingkat kevalidan atu kesahihan suatu instrumen. Suatu instrumen yang valid atau sahih mempunyai validitas tinggi. Guna melakukan uji validitas ini menggunakan program SPSS versi 21.0 Uji validitas menggunakan rumus dengan teknik Paired Sample T-test (korelasi personn Product Moment). Reliabilitas menunjukan tingkat kemantapan suatu data.Dalam hal peneliti melakukan uji reliabilitas dengan menggunakan program SPSS Versi 21.0 dengan teknik metode Alpha.

Teknik analisis data yang digunakan dalam penelitian ini adalah teknik kuantitatif analisis data ini dengan menggunakan program SPSS Versi 21.0. Uji normalitas ini digunakan untuk mengetahui kenormalan data.Rumus yang digunakan adalah uji histrogram, uji normal $P$ Plot, Uji Chi Square, Skweness dan Kurtosisatau uji Kolmogorov-Smirnov. Dalam melakukan uji beda rata-rata dengan bantuan program SPSS Versi 21.0menggunakan uji dua data yang berpasangan (Paired samples T test). Hipotesis dalam penelitian ini adalah ada perbedaan hasil belajar Sejarah dengan menggunakan model pembelajaran Student Facilitator And Explainning dan Mind Mapping Kelas X di SMA Plus Bina Satria Rupit. 


\section{HASIL DAN PEMBAHASAN}

Pelaksanaan penelitian ini dilaksanakan SMA Plus Bina Satria Rupit Tahun Ajaran 2020/2021 dengan materi teori-teori masuk dan berkembangnya Hindu-Buddha di Nusantara.Penelitian ini dilaksanakan pada tanggal 29 Juli sampai dengan 29 Agustus 2020.Peneliti melakukan uji validitas sebelum melakukan penelitian atau peneliti terlebih dahulu melaksanaakan uji instrumen dengan materi teori-teori masuk dan berkembangnya Hindu-Buddha di Nusantara. Uji instrumen ini dilakukan pada hari Rabu 26 Juli 2020, adapun peserta uji instrumen adalah siswa kelas XI IPS 1 SMA Plus Bina Satria yang berjumlah 30 siswa.

Uji instrumen ini dilakukan untuk mengatahui kualitas soal digunakan atau tidak sebagai instrumen untuk mengambil data dalam proses penelitian. Penelitian inidilaksanakan pada dua kelas dengan rincian empat pertemuan pelajaran sejarah dua pertemuan pelajaran di kelas X. IPS 1 (kelas eksperimen I) dan dua pertemuan pelajaran di kelas X. IPS 3 (kelas eksperimen II).

Data hasil Pre-Test dan Post-Test kelas eksperimen I model pembelajaran Student Facilitator And Explainning serta data hasil Pre-Test dan Post-Test kelas Eksperimen II model pembelajaran Mind Mapping memiliki perbedaan nilai rata-rata hasil belajar siswa.

Perbedaan Hasil Belajar Kelas Eksperimen I dan Eksperimen II

\begin{tabular}{ccc}
\hline Nilai & \multicolumn{2}{c}{ Rata-Rata } \\
\cline { 2 - 3 } & Eksperimen I & Eksperimen II \\
\hline Pre-Test & 55,18 & 54,3 \\
\hline Post-Test & 81,32 & 76,53 \\
\hline
\end{tabular}

Tabel di atas nilai menunjukkan bahwa pre-test kelas eksperimen I model pembelajaran Student Facilitator And Explainning dengan jumlah nilai rata-rata sebesar 55,18 sedangkan nilai pre-test kelas Eksperimen II model pembelajaran Mind Mapping dengan jumlah nilai rata-rata 54,3. Selanjutnya nilai post-test kelas eksperimen I model pembelajaran Student Facilitator And Explainning dengan jumlah nilai rata-rata sebesar 81,32 sedangkan nilai post-test kelas eksperimen II model pembelajaran Mind Mapping dengan jumlah nilai rata-rata 76,53. Menggunakan bantuan program SPSS versi 21.0.Kriteria penguji normalitas yaitu jika lebih dari 0.05 , maka dapat disimpulkan bahwa data tersebut berdistribusi normal.jika kurang dari 0.05, maka dapat disimpulkan bahwa data tersebut berdistribusi tidak normal.

Rekapitulasi Data Uji Normalitas

\begin{tabular}{cccccc}
\hline No & Data & Kelas & Sig. & Kriteria & Kesimpulan \\
\hline \multirow{2}{*}{1} & Pre-Test & $\begin{array}{c}\text { Ekperimen I(Model Student } \\
\text { Facilitator And Explaining) }\end{array}$ & 0,191 & Sig $>0,05$ & Normal \\
\cline { 2 - 6 } & $\begin{array}{c}\text { Ekspeimen II(Model Mind } \\
\text { Mapping) }\end{array}$ & 0,200 & Sig $>0,05$ & Normal \\
\hline 2 & Post-Test & Eksperimen I & 0,200 & Sig $>0,05$ & Normal \\
\hline
\end{tabular}


(Model Student Facilitator AndExplainnin)

Ekspeimen II(Model Mind Mapping)

0,151 Sig $>0,05 \quad$ Normal

Berdasarkan tabel di atas menunjukkan bahwa data pre-test kelas eksperimen I model Student Facilitator AndExplainning memiliki nilai signifikansi sebesar 0,191 jika dibandingkan dengan 0,05, maka 0,200>0,05 dengan demikian sampel data berdistribusi normal, selanjutnya data pre-test kelas eksperimen II model Mind Mapping memiliki nilai signifikansi sebesar 0,200 jika dibandingkan dengan 0,05, maka 0,200>0,05 dengan demikian sampel data berdistribusi normal. Kemudian data post-test kelas eksperimen I memiliki nilai 0,200 jika dibandingkan dengan 0,05, maka 0,200 > 0,05 dengan demikian sampel data berdistribusi normal, dan data post-test kelas Eksperimen II memiliki nilai 0,151 jika dibandingkan dengan 0,05, maka, 0,151 > 0,05 dengan demikian sampel data berdistribusi normal.

Berdasarkan hasil perhitungan dengan mengunakan bantuan program SPSS versi 21.0. Kriteria penguji homogenitas jika seluruh variabel lebih dari 0.05 , maka dapat disimpulkan bahwa data tersebut adalah homogen. Jika seluruh variabel kurang dari 0.05 , maka dapat disimpulkan bahwa data tersebut tidak homogen.Untuk rekapitulasi hasil perhitungan uji homogenitas dapat dilihat pada tabel di bawah ini

Rekapitulasi Data Uji Homogenitas Pre-Test dan Post-Test

\begin{tabular}{|c|c|c|c|c|}
\hline No & Data & Siq. & Kriteria & Kesimpulan \\
\hline 1 & Pre-Test & 0,678 & Sig $>0,05$ & Homogen \\
\hline 2 & Pos-Test & 0,670 & Sig $>0,05$ & Homogen \\
\hline
\end{tabular}

Tabel di atas menunjukkan bahwa data pre-test memiliki nilai signifikansi sebesar 0,678 jika dibandingkan dengan 0,05, maka 0,678> 0,05 dengan demikian varians data bersifat homogen, selanjutnya data post-test memiliki nilai signifikansi sebesar 0,670 jika dibandingkan dengan 0,05, maka 0,670>0,05 dengan demikian varians data brsifat homogen.

Berdasarkan hasil uji normalitas dan homogenitas didapatkan kedua kelompok data baik pre-test maupun post-test adalah normal dan homogen. Oleh karena itu dapat dilakukan uji hipotesis yaitu dengan uji beda dua rata-rata antara kelas eksperimen I dan kelas eksperimen II dengan data pre-test dan post-test dengan mengunakan bantuan SPSS Versi 21.0. Berdasarkan analisis perhitungan untuk data tes awal dan tes akhir dapat dilihat pada tabel berikut. 


\begin{tabular}{ccccc}
\hline \multirow{2}{*}{ No } & Kelas & Deskripsi & $\begin{array}{c}\text { Eksperimen I menggunakan } \\
\text { model pembelajaran Student } \\
\text { Facilitator And Explainning }\end{array}$ & $\begin{array}{c}\text { Eksperimen II } \\
\text { menggunakan model } \\
\text { pembelajaran Mind } \\
\text { Mapping }\end{array}$ \\
\hline \multirow{2}{*}{1} & \multirow{2}{*}{ Pretest } & $\mathrm{Mean}$ & 55.18 & 54,30 \\
\cline { 3 - 5 } & & $\mathrm{N}$ & 28 & 30 \\
\cline { 3 - 5 } & & Standar deviasi & 11.563 & 10.986 \\
\cline { 3 - 5 } 2 & Posttest & $\mathrm{N}$ & 81,32 & 36,53 \\
\cline { 3 - 5 } & & Standar deviasi & 28 & 30 \\
\hline 3 & Analisis & Sig. (2-tailed) & 8,940 & .000 \\
\hline
\end{tabular}

Tabel di atas menunjukkan bahwa Sig. (2-tailed) lebih kecil dari pada kriteria 0,05. Hasil analisis data menggunakan uji beda rata-rata nilai tes akhir di Sig. (2-tailed) adalah 0,000. Jika dibandingkan dengan 0,05. Maka 0,000<0,05. Dengan demikian artinya ada perbedaan penggunaan model pembelajaran Student Facilitator And Explainning terhadap hasil belajar sejarah pada siswa kelas X IPS di SMA Plus Bina Satria Rupit. Hal tersebut membuktikan bahwa model pembelajaran Student Facilitator And Explainning mempunyai perbedaan dalam meningkatkan hasil belajar siswa di bandingkan model pembelajaran Mind Mapping.

Penelitian ini dilakukan pada tanggal 29 Juli 2020 sampai tanggal 29 Agustus 2020 pada semester ganjil tahun pelajaran 2020/2021. Sebelum memulai kegiatan penelitian, terlebih dahulu dilakukan uji coba instrumen. Uji coba instrumen bertujuan untuk mengetahui kualitas soal yang akan digunakan penelitian dalam kelas eksperimen I dan kelas eksperimen II. Uji coba instrumen dilakukan di kelas XI IPS di SMA Plus Bina Satria Rupit pada hari Kamis 30 Juli 2020 tahun pelajaran 2020/2021 dengan jumlah siswa 30 orang dengan materi teori-teori masuk dan berkembangnya Hindu-Buddha di Nusantara. Dari 40 soal yang diujikan hanya ada 10 soal yang tidak valid dan 30 soal lainnya valid, dengan demikian peneliti hanya menggunakan soal yang valid untuk pre-test dan post-test.

Pertemuan yang dilaksanakan penulis pada kelas eksperimen I maupun di kelas eksperimen II adalah sebanyak 4 kali pertemuan adanya virus corona jadi pembelajaran sekolah dipercepat 1 jam pelajaran yaitu 25 menit dengan total 8 jam pembelajaran (200 menit), bahwa dengan adanya permasalahan dengan keadaan Dunia pada saat ini adanya virus Corona atau Covid-19 peneliti melakukan pembelajaran sebanyak 4 kali pertemuan dimana pihak sekolah menentukan satu kelas itu dibagi 2 kelas yaitu kelas ganjil dan kelas genap.

Pertemuan pertama kelas eksperimen I (kelas ganjil ) dilakukan pada hari Senin tanggal 3 Agustus 2020 dengan waktu pembelajaran 2 jam pelajaran. Satu jam pertama dilakukan pretest, selanjutnya satu jam berikutnya dilakukan dengan pemberian materi tentang teori-teori 
masuk dan berkembangnya Hindu-Buddha di Nusantara.Pertemuan pertama kelas eksperimen I (kelas genap) dilakukan pada hari selasa tanggal 4 Agustus 2020 dengan waktu pembelajaran 2 jam pelajaran. Satu jam pertama dilakukan pre-test, selanjutnya satu jam berikutnya dilakukan dengan pemberian materi tentang teori-teori masuk dan berkembangnya Hindu-Buddha di Nusantara.

Kemudian di kelas eksperimen II (kelas ganjil) dilakukan dihari rabu 5 Agustus 2020 dengan jumlah 2 jam pembelajaran. Satu jam pertama dilakukan untuk pre-test, dan satu jam yang berikutnya dilanjutkan dengan pemberian materi teori-teori masuk dan berkembangnya Hindu-Buddha di Nusantara. Pertemuan kelas eksperimen II (kelas genap) dilakukan dihari kamis 6 Agustus 2020 dengan jumlah 2 jam pembelajaran. Satu jam pertama dilakukan untuk pre-test, dan satu jam yang berikutnya dilanjutkan dengan pemberian materi teori-teori masuk dan berkembangnya Hindu-Buddha di Nusantara.

Pertemuan kedua kelas eksperimen I (kelas gaanjil dan kelas genap) dilakukan pada hari Senin 10 Agustus 2020 dan Selasa 11 Agustus 2020 dengan waktu pembelajaran 2 jam. Satu jam pertama dilakukan untuk menerapkan model Student Facilitator And Explainning dengan materi teori-teori masuk dan berkembangnya Hindu-Buddha di Nusantara. Selanjutnya satu jam berikutnya dilanjutkan dengan post-test. Kemudian di kelas eksperimen II (kelas ganjil dan kelas genap) dilakukan pada hari Rabu tanggal 12 Agustus 2020 dan Kamis 13 Agustus 2020 dengan jumlah 2 jam pelajaran. Satu jam pertama dilakukan untuk menerapkan model pembelajaran Mind Mapping dengan materiteori-teori masuk dan berkembangnya HinduBuddha di Nusantara. Selanjutnya satu jam sisahnya digunakan untuk melakukan post-test.

Analisis tes awal pada kelas eksperimen I dan kelas eksperimen II tidak menunjukan adanya perbedaan yang begitu besar. Dengan nilai rata-rata pre-test pada kelas eksperimen I sebesar 54,54 dan pada kelas eksperimen II sebesar 53,67. Hal ini berarti rata-rata kemampuan siswa kelas eksperimen I dan kelas eksperimen II berbeda karena masih mendapatkan perlakuan yang sama pada tes awal. Pada analisis data tes akhir terdapat perbedaan hasil belajar antara kelas eksperimen I dan kelas eksperimen II. Nilai rata-rata post-test pada kelas eksperimen I sebesar 81,32 sedangkan pada kelas eksperimen II sebesar 76,53. Dengan demikian berarti nilai rata-rata kelas eksperimen I lebih besar dari kelas eksperimen II.Hal tesebut disebabkan karena perlakuan pembelajaran yang diberikan berbeda. Pada kelas eksperimen I mengunakan model pembelajaran Student Fcailitator And Explainning, Sedangkan pada kelas eksperimen II mengunakan model pembelajaran Mind Mapping Adapun untuk mengatahui pengaruh antara hasil belajar kelas eksperimen I dan kelas eksperimen II.

Pada hasil data penelitian diatas, SMA Plus Bina Satria Rupit dapat di simpulkan Ada perbedaan hasil belajar sejarah dengan model pembelajaran Student Facilitator And Explainning dan Mind Mapping kelas X di SMA Plus Bina Satria Rupit. Hal ini dapat dilihat dari 
hasil nilai rata-rata pre-test pada kelas eksperimen I sebesar 55,18 dan pada kelas eksperimen II sebesar 54,30. Sedangkan nilai rata-rata post-test pada kelas eksperimen I setelah diberikan perlakuan dengan menggunakan model Student Facilitator And Explainningsebesar 81,32, dan kelas eksperimen II dengan model pembelajaran Mind Mapping sebesar 76,53.

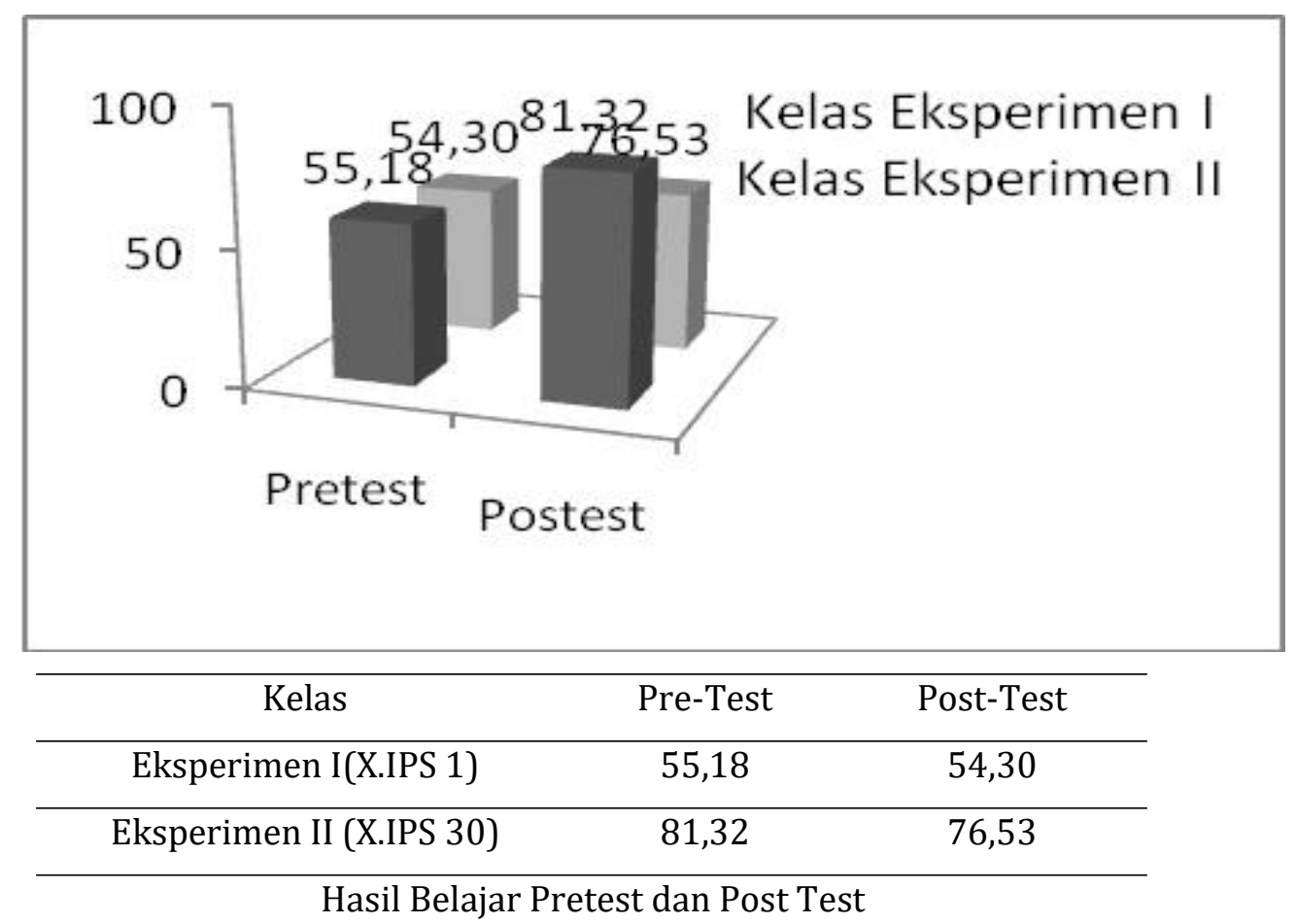

Pada hasil data penelitian diatas, dengan menggunakan model pembelajaran Student Facilitator And Explainning dan Mind Mapping Kelas X di SMA Plus Bina Satria Rupit ada perbedaan hasil belajar sejarah. Bahwa model Student Facilitator And Explainningsiswalebih aktif dan lebih baik belajar sejarah karena mempunyai kelebihan, dibandingkan dengan menggunakan model Mind Mapping siswa kurang aktif dan cenderung pasif menggunakan model Mind Mapping karena mempunyai kelemahanya menurut (Kurnia,Sani 2016:54)yaitu tidak sepenuhnya murid yang belajar, jumlah detail informasi tidak dapat dimasukkan.

Pada hasil data penelitian di atas, bahwa dari penelitian yang relevan yaitu penelitian yang telah dilakukan oleh Yuliana, dkk (2018:139) yang berjudul perbandingan model Student Facilitator And explainning terhadap hasil belajar siswa dengan memperhatikan kemampuuan awal menyatakan bahwa penggunaan model Student Facilitator And Explaining dapat meningkatkan hasil belajar siswa dibandingkan model pembelajaran Cooperative Script dapat meningkatkan hasil belajar lebih rendah. Sedangkan menurut Widyastuti dan Sukarjo (2018:47) yang berjudul Keefektifan model Student Facilitator And Explainning berbantuan Mind Mapping terhadap hasil belajar siswa menyatakan bahwa model Student Facilittaor And Explainning berbantuan Mind Mapping lebih efektif dan meningkatkan hasil belajar.

Dari beberapa pendapat diatas maka dapat disimpulkan bahwa model pembelajaran Student Facilitator And Explainning dan Mind Mapping tersebut sama-sama memiliki 
perbedaan yang sangat tinggi terhadap hasil belajar siswa, dari hasil penelitian relevan diatas mempunyai hubungan dengan penulis yang lakukan. Karena di dalam sama-sama menggunakan model pembelajaran Student Facilitator And Explainning dan Mind Mapping, sehingga peneliti di anggap relevan karena memiliki tujuan yang sama-sama untuk dapat meningkatkan hasil belajar siswa. Peneliti yang dilakukan di SMA Plus Bina Satria Rupit ini bertujuan untuk memudahkan guru dalam melaksanakan guru dalam melaksanakan proses pembelajaran berlangsung demi tercapainya tujuan pembelajaran yang efektif dan efisien.

\section{KESIMPULAN}

Berdasarkan hasil analisis data penelitian, yang dilakukan di SMA Plus Bina Satria Rupit dapat di simpulkan Ada perbedaan hasil belajar sejarah dengan model pembelajaran Student Facilitator And Explainning dan Mind Mapping kelas X di SMA Plus Bina Satria Rupit. Hal ini dapat dilihat dari hasil nilai rata-rata pre-test pada kelas eksperimen I sebesar 55,18dan pada kelas eksperimen II sebesar 54,30. Sedangkan nilai rata-rata post-test pada kelas eksperimen I setelah diberikan perlakuan dengan menggunakan model Student Facilitator And Explainning sebesar 81,32, dan kelas eksperimen II dengan model pembelajaran Mind Mapping sebesar 76,53. Dengan demikian berarti nilai rata-rata kelas eksperimen I lebih besar dari kelas eksperimen II. Dimana nilai signifikansi lebih kecil dibandingkan dengan 0,05, yaitu 0,00<0,05. Dengan demikian Ho ditolak dan Ha diterima artinya ada perbedaan hasil belajar sejarah dengan model pembelajaran Student Facilitator And Explainning dan Mind Mapping kelas X di SMA Plus Bina Satria Rupit dapat diterima kebenarannya.

\section{REFERENSI}

Aman.2011. Model dan Evaluasi Pembelajaran Sejarah. Yogyakarta: Ombak.

Amin,dkk.2016.Model Pembelajaran Ilmu Pengetahuan Sosial (IPS) Pada Materi Kontroversi (Countroversy Issues) di Sekolah SMP Kota Semarang. 33 (1) hal.(19-20)

Arsa, 2015.Belajar dan Pembelajaran Strategi Belajar yang menyenangkan.Yogyakarta: Media Akademi.

Arikunto, Suharisimi. 2013. Prosedur Penelitian Suatu Pendekatan Praktik. Jakarta: Rineka Cipta. Aunnurrahman.2016. Belajar dan Pembelajaran.Bandung: Alfabeta.

Aqib, Zainal.2013. Model-model, Media, dan Strategi Pembeljaran Kontekstual (Inovatif). Bandung. Cv Yrama Widya

Anshori Al Junaedi.2011. Masa Prasejarah Sampai Masa ReformasiKemerdekaan. Jakarta: PT Mitra Aksara Panaitan

Budiyanto, Krisno Agus. 2016. Sintanks 45 Metode Pembelajaran dalam Student Centered Learning (SCL). Malang: Universitas Muhammaiyah Malang. 
Darmawan, Edi.2013. Metode Penelitian Kuantitatif. Yogyakarta: Rosda

Helmiati. 2016. Model Pembelajaran.Yogyakarta: Aswaja Pressindo.

Huda, M.2014. Model-model Pengajaran dan Pembelajaran.Yogyakarta: Pustaka Belajar

Jihad, Asep dan Haris, Abdul. 2010. Evaluasi Pembelajaran. Yongyakarta: Multi Presindo.

Kurniasih, Sani.2015. Ragam Pengembangan Model Pembelajaran Untuk Peningkatan Profeionalitas Guru: Kata Pena

Kholik, dkk.2013. Pengantar Ilmu Pendidikan. Bogor: Unida Press

Mawanto, S.2018.Implementasi Mind Mapping Dalam Pembelajaran Sejarah Untuk Meningkatkan Hasil Belajar Siswa di SMA Muhammadiyah 3 Yogyakarta. Jurnal Penelitian dan Kajian Pendidikan. 8 (2), hal, (97)

Poesponegoro, Notosusanto.1993. Sejarah Nasional Indonesia II.Jakarta: Balai Pustaka

Saifullah, Ali.2013. Antara filsafat dan pendidikan pengantar Filsafat Pendidikan. Surabaya: Usaha Nasional.

Sudirman, A.2014. Sejarah Lengkap Indonesia.Yogyakarta:Diva Press

Sudjiono, A.2010. Pengantar Evaluasi Pendidikan. Jakarta:Raja Grafindo Persada

Sugiyono.2017. Metode Penelitian Pendidikan.Bandung: Alfabeta

Sunjoyo,dkk.2013.Aplikasi SPS untuk Smart Riset Program IMB SPPS 21.Bandung.Alfabeta

Suratno. 2013. Meningkatkan Pemahaman Konsep Peninggalan Sejarah Hindu di Indonesia Melalui Startegi Pembelajaran Inkuiri Sosial di Kelas V SDN 2 Buga Kabupaten Tolitoli.Jurnal Kreatif Tadulako Online. 2 (10) hal (14-15)

Triwiyanto, Teguh. 2014. Pengantar Pendidikan. Jakarta:Pt Bumi Aksara.

Thobroni, M.2015. Belajar dan Pembelajaran.Yogyakarta: Ar Ruzz Media.

Widiyastuti dan Sukarjo.2018.Keefektifan Model Student Facilitator and Explainning Berbantuan Mind Map Terhadap Hasil Belajar IPS.Joyful Learning Journal.7 (3) hal. (47)

Winarsih,dkk.2019. Materi Sejarah Masa Hindu-Buddha dan Penggunaan Sumber Belajar Sejarah dalam Pembelajarannya di SMK.Journal Tamaddun: Jurnal Sejarah Kebudayaan Islam. 7(2) hal. (333-334)

Wijayanti, dkk.2019.Keefektifan Model Pembelajaran Student Facilitator And Explainning Berbasis Media Timeline Char Terhadap Hasil Belajar IPS. Journal for lesson and learning.2 (3) hal (122-123)

Yuliana ,dkk.2018.Perbandingan Model Student Facilitator and Explainning dan CS Terhadap Hasil belajar Siswa Dengan Memperhatikan Kemampuan Awal.Jurnal Studi Sosial. 6 (2) hal, (54-55) 